\title{
Detection of chikungunya virus in the Southern region, Saudi Arabia
}

\author{
Abdulrahim R. Hakami ${ }^{*}{ }^{*}$, Abdullah A. Alshamrani ${ }^{1}$, Mohamad Alqahtani $^{1}$, Yasser Alraey ${ }^{1}$, Razan A. Alhefzi ${ }^{1}$, \\ Sultan Alasmari ${ }^{1}$, Mohamed Makkawi ${ }^{1}$, Gasim Dobie ${ }^{2}$, Mushtaq Mir ${ }^{1}$, Mohamed Alshahrani ${ }^{1}$, Ayed Dera', \\ Mohammed Alfaifi ${ }^{1}$, Mesfer Al Shahrani ${ }^{1}$, Ahmad Matari ${ }^{3}$ and Ali Essa Asiry ${ }^{4}$
}

\begin{abstract}
Background and aim: Despite the fact that the chikungunya viral infection is a neglected disease, complications such as hemorrhagic fever, arthritis, and lymphopenia remain a health concern. The aim of this study was to determine the prevalence of the chikungunya virus in the Southern Region, Saudi Arabia. Enzyme immunoassay and polymerase chain reaction have been compared between samples.

Materials and methods: Forty samples from two southern hospitals in Saudi Arabia were collected between December 2019 and February 2020 and screened for chikungunya virus lgG antibodies and for viral RNA. Selection criteria were based on hematological parameters and rheumatological profiles such as rheumatoid factor, c-reactive protein, anti-nuclear antibody, and anti-cyclic citrullinated peptide (anti-CCP) of out-patients.

Results: One confirmed case of chikungunya virus was detected using the ELISA test. However, no viral RNA was detected in any of the samples. This suggests that the virus is cleared rapidly in patients.

Conclusion: Chikungunya is a neglected viral disease in Saudi Arabia. Future work should focus on detailed investigation of this viral infection and its vectors.
\end{abstract}

Keywords: Chikungunya, Hemorrhagic fever, Mosquitoes, Thrombocytopenia

\section{Introduction}

Arboviruses are arthropod-borne viruses that can be transmitted from ticks and mosquitoes to humans and animals. Chikungunya virus belongs to the Togaviridae family and alphavirus genus that is transmitted by mosquitoes, and is considered a neglected tropical disease [1]. The Jazan Region, Saudi Arabia, lies within the tropical zone, and is known by its hot climate. It is dominated by mosquitoes that can transmit hemorrhagic viruses such as dengue. Rift Valley fever (RVF) virus is another arbovirus that emerged in the Jazan Region for the first time in 2000 [2].

\footnotetext{
*Correspondence: ahakami@kku.edu.sa

${ }^{1}$ Department of Clinical Laboratory Sciences, College of Applied Medical Sciences, King Khalid University, Abha 61481, Saudi Arabia
}

Full list of author information is available at the end of the article
Arboviruses, which include the families Flaviviridae and Togaviridae, cause hemorrhagic fever which is known as "bone-breaker fever" [3]. In Saudi Arabia, dengue cases between 2013 and 2015 have been reported mainly in Makkah and Jeddah, while very few cases were reported in the Jazan and Asir regions [4]. Moreover, the chikungunya virus was reported in Jeddah for the first time in 2011 following a positive quantitative real-time polymerase chain reaction (qRTPCR) result for a 55-year-old women who suffered from severe arthralgia [5]. IgM and IgG antibodies against the virus were detected. The chikungunya virus is characterized by rapid onset of fever, short viremia, rash, arthralgia, skin bleeding, hemorrhagic dyscrasia, joint swelling, elevated c-reactive protein, leukopenia, and normal or low platelet count [6]. Other reported original author(s) and the source, provide a link to the Creative Commons licence, and indicate if changes were made. The images or other third party material in this article are included in the article's Creative Commons licence, unless indicated otherwise in a credit line to the material. If material is not included in the article's Creative Commons licence and your intended use is not permitted by statutory regulation or exceeds the permitted use, you will need to obtain permission directly from the copyright holder. To view a copy of this licence, visit http://creativecommons.org/licenses/by/4.0/. The Creative Commons Public Domain Dedication waiver (http://creativeco mmons.org/publicdomain/zero/1.0/) applies to the data made available in this article, unless otherwise stated in a credit line to the data. 
manifestations include seizure, jaundice, gastrointestinal bleeding, pulmonary hemorrhage, intracranial hemorrhage, conjunctival bleeding, cyanosis, and even death in neonates [7-11].

Mosquito diversity and abundance vary between the Asir and Jazan regions due to the huge climatic and geographical variation between the two regions $[12,13]$. In general, the Aedes species have not been reported at the highlands of the Asir region. Nevertheless, the endemicity of dengue virus has been confirmed only in the Tihamah part of the Asir region (Tihāmat Asīr) which is similar to the Jazan region in terms of climate conditions $[14,15]$, which suggests the prevalence of Aedes species in this area. The most significant human viral diseases including dengue, chikungunya, and zika are mainly transmitted globally by Aedes aegypti and Aedes albopictus. Therefore, controlling the Aedes species using insecticide and providing risk maps with vector populations will help to reduce the arboviruses transmission [16]. To the contrary, the threat of insecticide resistance to multiple insecticides (e.g. pyrethroids and organophosphates) still exists, and, therefore, looking for an alternative control measurements is highly recommended $[4,17]$. The objective of this study was to determine whether the chikungunya virus is circulating in two different Saudi
Arabian southern regions by comparing the results of enzyme-linked immunosorbent assay (ELISA) and PCR.

\section{Materials and methods \\ Sample collection}

To increase the chance for detection of an arbovirus that has not been extensively studied, inclusion criteria should focus on proper sample selection. The most common clinical presentations of arboviruses including the chikungunya virus are joint pain and bleeding. Abnormal platelet and white blood cells (WBCs) are other important laboratory profiles. Serum samples from arthritis patients and patients with hemorrhagic fever were collected from different altitudes: 30 serum samples from Asir Central Hospital and 10 patients from Baish General Hospital in the Jazan Region (Fig. 1), where Aedes aegypti mosquitoes thrive. The collection was conducted in the winter season between December 2019 and February 2020 where cases of hemorrhagic fever dominate. At Asir Central Hospital, 30 samples were selected after they had been sent to the laboratory based on the physicians' requests for rheumatological profiles (rheumatoid factor, c-reactive protein, anti-nuclear antibody, and anti-cyclic citrullinated peptide (anti-CCP) of outpatients). Those patients were clinically diagnosed with

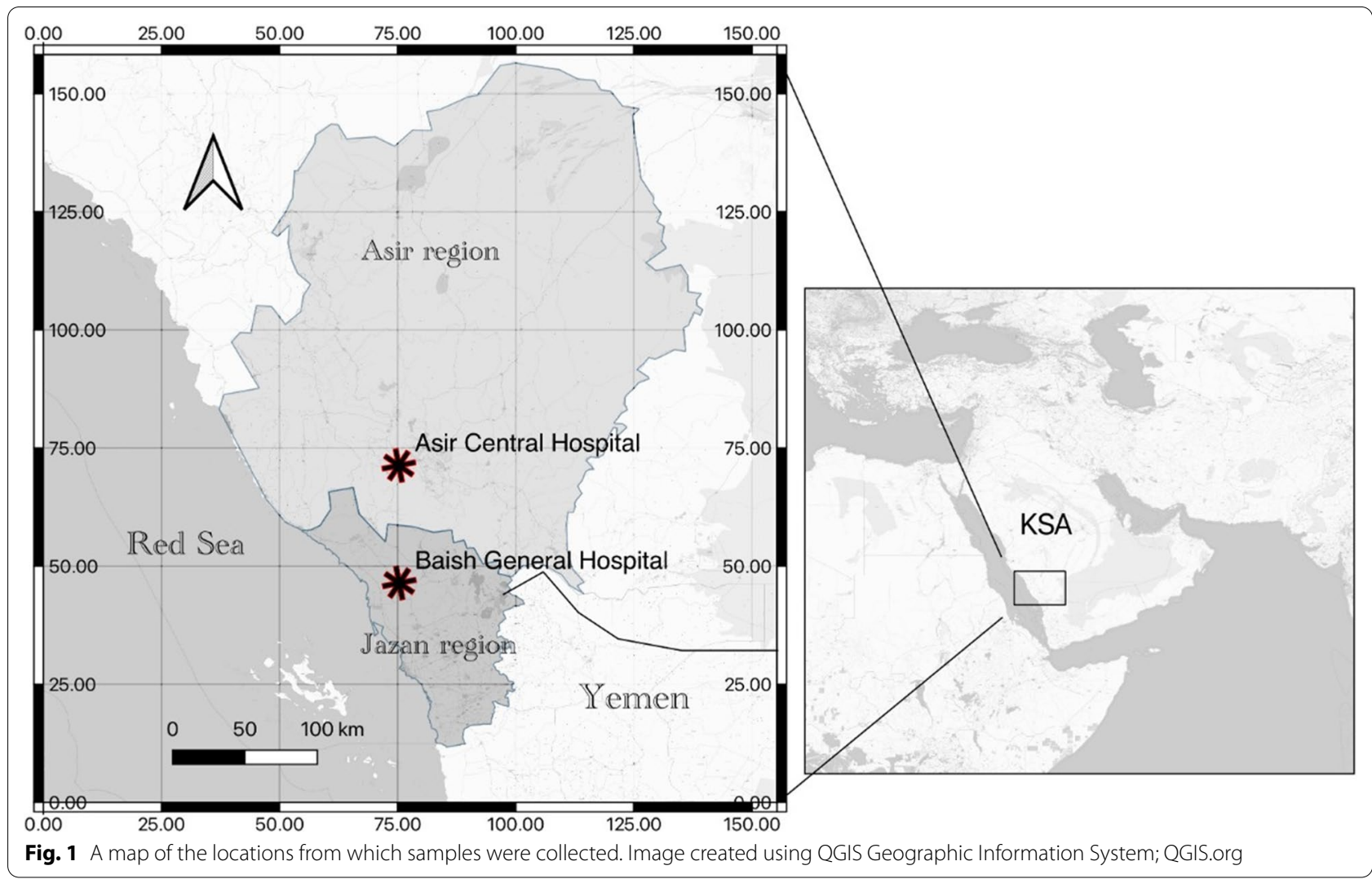


rheumatoid arthritis. At Baish General Hospital, samples from patients with nasal bleedings who were admitted to the hospital were selected.

\section{Detection of anti-chikungunya virus IgG}

Anti-chikungunya virus IgG class antibodies were qualitatively measured using enzyme immunoassay with the sandwich type based on avidin-biotin binding. Antihuman IgG antibodies were pre-coated on the solid phase of 96-well microplate to cross-react with human antibodies in the serum. Following the addition of the controls and the 1:100-dilted serum samples, wells were washed. The chikungunya virus antigen (abcam, ab177835) was then added. After one hour of incubation time, chikungunya virus biotinylated antibodies were added, incubated, and washed, followed by the addition of streptavidin peroxidase conjugate. Tetramethylbenzidine (TMB) is catalyzed by the peroxidase enzyme. Absorbance was measured using a spectrophotometer at $450 \mathrm{~nm}$ wavelength using FLUOstar Omega (BMG LABTECH GmbH, Germany), and the color is directly proportional to the captured anti-chikungunya virus IgG antibody. Data and figures were presented using GraphPad Software, version 8, (San Diego, CA, USA).

\section{Extraction of viral RNA}

Viral nucleic acid was extracted using ABIOpure Viral, version 2.0, DNA/RNA Extraction kit, \#M561VT50, AllianceBio, USA. This uses advanced silica-binding technology to purify viral RNA that binds to the silica membrane, and finally the eluate was collected in a clean tube. The protocol was performed using $10 \mu \mathrm{l}$ proteinase K, $200 \mu \mathrm{l}$ sample, $7 \mu \mathrm{l}$ carrier RNA to enhance binding of viral nucleic acid to the spin column membrane, 200-400 $\mu \mathrm{l}$ of the intended buffer, and $20 \mu \mathrm{l}$ nuclease-free water.

\section{Reverse transcription PCR}

The following materials were obtained from meridian Bioscience $^{\mathrm{TM}}$, or otherwise stated. Reverse transcription polymerase chain reaction (RT-PCR) was used to detect the genome of chikungunya virus in blood samples. The forward primer AAGCTCCGCGTCCTTTACCAAG and the reverse primer CCAAATTGTCCTGGTCTTCCT [18] were synthesized by Eurofins Genomics, Germany (Table 1). The primer domains are conserved among chikungunya isolates that target the E gene (Fig. 2). The cDNA synthesis was performed according to Sensi$\mathrm{FAST}^{\mathrm{TM}}{ }^{\mathrm{cDNA}}$ Synthesis Kit protocol. The master mix was prepared on ice, and centrifuged briefly. One microgram of the viral RNA was used with $4 \mu$ of buffer and $1 \mu \mathrm{l}$ of reverse transcriptase enzyme. The reaction volume was topped up to $20 \mu \mathrm{l}$ with nuclease-free water, and mixed gently by pipetting. The thermal cycler was set up at $25{ }^{\circ} \mathrm{C}$ for $10 \mathrm{~min}$ (primer annealing), $42{ }^{\circ} \mathrm{C}$ for $15 \mathrm{~min}$ (reverse transcription), $8{ }^{\circ} \mathrm{C}$ for $5 \mathrm{~min}$ (inactivation), and then chilled on ice. To perform the PCR, the master mix and the cycling parameters were conducted according to the protocol of $\mathrm{MyTaq}^{\mathrm{TM}}$ Mix, meridian Bioscience ${ }^{\mathrm{TM}}$, United Kingdom (Table 1). RT-PCR was performed using BIO-RAD T100 ${ }^{\mathrm{TM}}$ Thermal Cycler.

\section{Results}

A positive case of the chikungunya virus

Rheumatological and hematological parameters of patients were considered. Patients with abnormal CBC and those who had been provisionally diagnosed with rheumatoid arthritis to whom samples were received at the hospital laboratory were the target of this study. Two groups of patients' samples were tested for the presence of anti-chikungunya virus and viral RNA detection. They were from Baish General Hospital (low altitude) in which ten samples were collected with abnormal $\mathrm{CBC}$, and the second group was from Asir

Table 1 List of chikungunya primers and PCR cycling parameters

\begin{tabular}{|c|c|c|c|}
\hline Primers & \multicolumn{2}{|c|}{ Sequence } & Size (bp) \\
\hline Forward CHIK 1 & \multicolumn{2}{|c|}{ AAGCTCCGCGTCCTTTACCAAG } & 208 \\
\hline Reverse CHIK 1 & \multicolumn{2}{|c|}{ CCAAATTGTCCTGGTCTTCCT } & \\
\hline \multicolumn{4}{|l|}{ Cycling parameters } \\
\hline Step & Cycles & Temperature & Time \\
\hline Initial Denaturation & 1 & 95 & $1 \mathrm{~min}$ \\
\hline Denaturation & 35 & 95 & $15 s$ \\
\hline Annealing & & 55 & $15 s$ \\
\hline Extension & & 72 & $10 \mathrm{~s}$ \\
\hline Final extension & 1 & 72 & $10 \mathrm{~s}$ \\
\hline
\end{tabular}




\section{GenBank}

JF274082. 1 (India)

MT526806.1 (Kenya)

MT526904.1 (Brazil)

MK028837.1 (Senegal)

MK028839.1 (USA)

MK028840.1 (Thailand)

\section{position}

$10374-10396$
$10376-10397$
$10417-10438$
$10592-10613$
$10383-10404$
$10133-10154$

$10374-10396$
Chikungunya Forward primer AAGCTCCGCGTCCTTTACCAAG AAGCTCCGCGTCCTTTACCAAG AAGCTCCGCGTCCTTTACCAAG AAGCTCCGCGTCCTTTACCAAG AAGCTCCGCGTCCTTTACCAAG AAGCTCCGCGTCCTTTACCAAG AAGCTCCGCGTCCTTTACCAAG

Chikungunya Reverse primer ССАAATTGTCCTGGTCTTCCT AGGAAGACCAGGACAATTTGG AgGAAGACCAGGACAATTTGG AGGAAGACCAGGACAATTTGG AGGAAGACCAGGACAATTTGG AGGAAGACCAGGACAATTTGG AGGAAGACCAGGACAATTTGG

Fig. 2 Mapping of primer domains of different chikungunya virus isolates

General Hospital (high altitude) who suffered from arthritis, in which 30 samples were collected. Only one sample was positive for the anti-chikungunya IgG antibodies, and one equivocal sample of duplicate tests. These two samples were from the first (low-altitude) group in which the Aedes mosquito thrives. They both showed abnormal low WBC and platelet counts (Fig. 3; Samples 6 and 9).

\section{Negative PCR tests suggest rapid clearance of chikungunya} virus

All samples were screened to detect chikungunya virus RNA following the viral extraction protocol, cDNA synthesis, and PCR. Gel electrophoresis was then prepared at a concentration of $2 \%$ agarose gel using UltraPure $^{\mathrm{TM}}$ Agarose, Invitrogen, 1X TAE buffer, and ethidium bromide (Sigma). Samples were loaded with DNA loading buffer and with HyperLadder $100 \mathrm{bp}$ (catalog number BIO-33056). No bands were observed for any samples. This suggests that the viremic state of the chikungunya patient is very short.

\section{Discussion}

During the winter season, patients were provisionally diagnosed with dengue fever virus, but no detection kits specific for arboviruses were available at the hospitals' laboratories that time. Patients with low WBC and low platelet count were selected from Baish General Hospital. Another cohort from Asir Central Hospital was included in the screening, using samples from patients who suffered from arthralgia. Another criterion for inclusion was the positivity of anti-CCP and rheumatoid factor (RF). These markers aided in the diagnosis of rheumatoid arthritis patients [19].

While the dengue virus caused severe morbidity and mortality in Saudi Arabia, the Southern Region is at risk of other arboviruses due to outbreaks in neighboring Yemen [20-24]. Dengue is not the only viral infection that is endemic in Saudi Arabia, but as chikungunya virus was also discovered. The Jazan Region in Saudi Arabia is a suitable habitat for Aedes mosquito breeding; the vector of the dengue and chikungunya virus. Although hemorrhage is considered a rare complication in chikungunya infection, the upsurge of hemorrhagic fever cases 
A

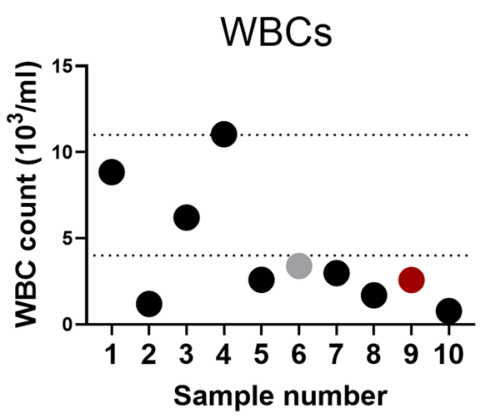

B

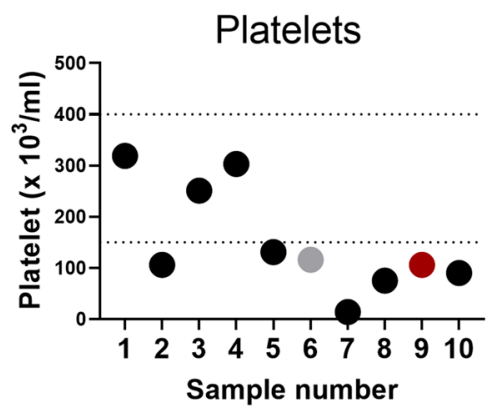

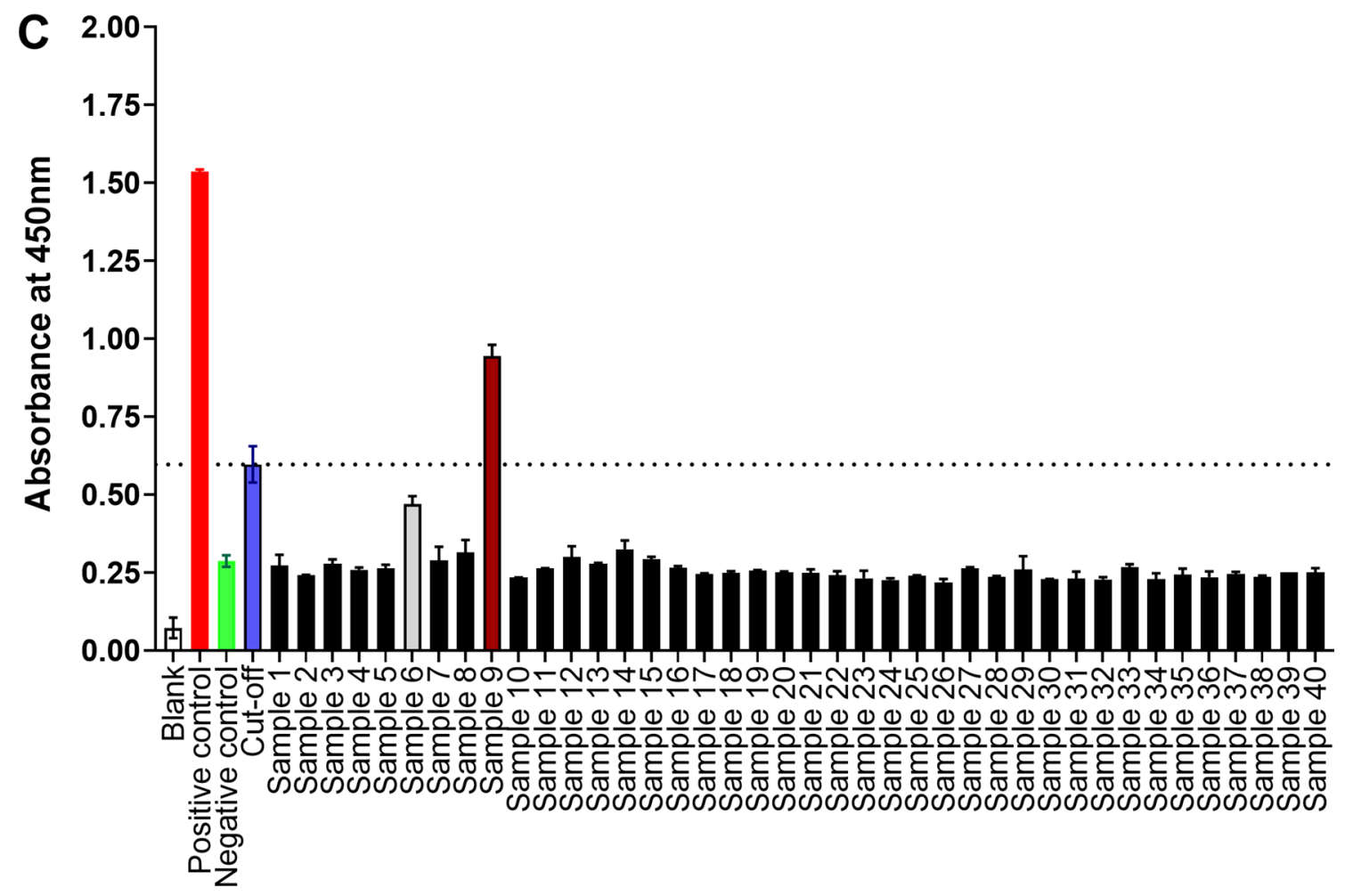

Fig. 3 CBC data and anti-chikungunya lgG results. Levels of WBCs (A) and platelets (B) of the first group of patients that were collected from Baish General Hospital (Samples 1 to 10) in which a confirmed chikungunya case was detected (Sample 9; scarlet) and an equivocal result (Sample 6; grey). (C) Results of anti-chikungunya virus lgG for all patients including arthritis patients that were collected from Asir Central Hospital (Samples 11 to 40). The dotted two lines (A and $\mathbf{B}$ ) indicate the normal range. The dotted line (C) indicates the cut-off value. Error bars represent $\pm S D$ of the mean

in Jazan during the breeding period of mosquitoes led us to investigate the prevalence of chikungunya infections in arthritic and hemorrhagic fever patients.

Patients' sera were screened for the presence of specific IgG antibodies to chikungunya virus. Platelet and WBCs count of seven patients from the first group were below the normal range. However, only one patient was found to be positive for anti-chikungunya IgG antibodies. In addition, sera were tested for the presence of the viral $E$ gene. However, results were all negative using RT-PCR. We believe that the virus was rapidly cleared by the host immune system. Having negative results for PCR suggests that the virus is characterized by a short viremic state. Infected patients clear the virus after one week of chikungunya infection [25].

Finally, it is important to note the limitations. Selecting specific samples that fit the inclusion criteria at the peak of infection from different locations would be 
challenging. Viral hemorrhagic cases are soared only in certain periods throughout the year. This drawback limited our ability to satisfactorily increase the sample size. Because the likelihood of detecting the chikungunya virus was low, and because PCR results were negative, the control sample size was moderate. Following initial chikungunya infection, the virus is shed after approximately one week. Therefore, the detection probability of viral nucleic acid would be restricted. The study is limited by the small sample size; however, samples from two different hospitals were collected. Patients might have arrived at the hospital after a week of the infection, and therefore, molecular detection of chikungunya was challenging and not possible, at least during our study. It was not possible to test IgM. Instead, molecular detection of the viral RNA was attempted to detect the acute phase of the chikungunya virus. While the background noise of the ELISA test seems somewhat high, the cut-off value $(\mathrm{COV})$ was set as a basis for the results interpretation. COV average (0.597 optical density) was higher than the negative control (0.287). Most samples were within the negative control range.

\section{Conclusion}

Out of 40 samples, one confirmed case of chikungunya virus was found after detecting anti-chikungunya IgG antibodies, but PCR showed negative results in all tested samples. Detection methods for the chikungunya virus are not applied routinely, and the virus might be circulating in regions where mosquitoes are abundant. Arboviruses such as the chikungunya virus should be considered a priority with health implications. There have been reports of death due to bleeding. A call to conduct extensive studies on such neglected infections is indeed required. Chikungunya is a neglected viral infection, and future work should focus on investigating the endemicity of arboviruses within the vector by performing a field work collection of Aedes species within selected areas. To avoid a large impact of any conclusion drawn from the small samples, a large sample size should be collected for future investigations.

\footnotetext{
Abbreviations

Anti-CCP: Anti-cyclic citrullinated peptide; COV: Cut-off value; ELISA: Enzymelinked immunosorbent assay; qRT-PCR: Quantitative real-time polymerase chain reaction; RT-PCR: Reverse transcription polymerase chain reaction; RVF: Rift valley fever; RF: Rheumatoid factor; TMB: Tetramethylbenzidine; WBC: White blood cell.
}

\section{Acknowledgements}

Not applicable.

\section{Authors' contributions}

AH: Funding acquisition, conceptualization and design, methodology, interpretation of results, writing original draft. AAA, MA, RA, and GD: Methodology, reviewing and editing. All authors have contributed to the writing of the manuscript, data curation, reviewing, editing the manuscript, and approved the final draft.

\section{Funding}

This work was funded by the Deanship of Scientific Research at King Khalid University [Grant No. GRP-185-41].

\section{Availability of data and materials}

All data generated or analyzed are presented in the manuscript. Accession numbers of chikungunya isolates are available at http://ncbi.nlm.nih.gov/ nuccore/

\section{Declarations}

\section{Ethical approval and consent to participate}

The project was approved by the Ethics Committee of the Scientific Research Deanship, King Khalid University, Saudi Arabia; approval number: (ECM\#2019-64)-(HAPO-06-B-001).

\section{Consent to publication}

Not applicable.

\section{Competing interests}

The authors declare that they have no competing interests.

\section{Author details}

${ }^{1}$ Department of Clinical Laboratory Sciences, College of Applied Medical Sciences, King Khalid University, Abha 61481, Saudi Arabia. ${ }^{2}$ Department of Medical Laboratory Technology, Jazan University, Jazan, Saudi Arabia. ${ }^{3}$ Department of Hematology and Blood Bank, Baish General Hospital, Jazan, Saudi Arabia. ${ }^{4}$ Department of Serology, Asir Central Hospital, Abha, Saudi Arabia.

Received: 11 June 2021 Accepted: 14 September 2021

Published online: 20 September 2021

\section{References}

1. Rougeron V, Sam I-C, Caron M, Nkoghe D, Leroy E, Roques P. Chikungunya, a paradigm of neglected tropical disease that emerged to be a new health global risk. J Clin Virol. 2015;64:144-52.

2. Al-Azraqi TA, El Mekki AA, Mahfouz AA. Rift Valley Fever in Southwestern Saudi Arabia: a sero-epidemiological study seven years after the outbreak of 2000-2001. Acta Trop. 2012;123:111-6.

3. Pfeffer M, Dobler G, Löscher T, Hassler D. Bone-breaker fever" in paradise. Chikungunya fever raged on dreamy tropical islands before it did on the east coast of Africa. Dtsch Med Wochenschr. 2006;131:601-2.

4. Al Nazawi AM, Aqili J, Alzahrani M, McCall PJ, Weetman D. Combined target site (kdr) mutations play a primary role in highly pyrethroid resistant phenotypes of Aedes aegypti from Saudi Arabia. Parasit Vectors. 2017:10:161.

5. Hussain R, Alomar I, Memish ZA. Chikungunya virus: emergence of an arthritic arbovirus in Jeddah, Saudi Arabia. East Mediterr Health J. 2013;19:506-8.

6. Silva JVJ, Ludwig-Begall LF, de Oliveira-Filho EF, Oliveira RAS, DurãesCarvalho R, Lopes TRR, et al. A scoping review of Chikungunya virus infection: epidemiology, clinical characteristics, viral co-circulation complications, and control. Acta Trop. 2018;188:213-24.

7. Ferreira FCPDADM, da Silva ASV, Recht J, Guaraldo L, Moreira MEL, de Siqueira AM, et al. Vertical transmission of chikungunya virus: a systematic review. PLoS ONE. 2021;16:e0249166.

8. Oliveira RMAB, Barreto FKDA, Maia AMPC, Gomes IP, Simião AR, Barbosa $\mathrm{RB}$, et al. Maternal and infant death after probable vertical transmission of chikungunya virus in Brazil: case report. BMC Infect Dis. 2018;18:333.

9. Gérardin P, Barau G, Michault A, Bintner M, Randrianaivo H, Choker G, et al. Multidisciplinary prospective study of mother-to-child chikungunya virus infections on the island of La Réunion. PLoS Med. 2008;5:e60.

10. Shah KV, Gibbs CJ, Banerjee G. Virological investigation of the epidemic of haemorrhagic fever in Calcutta: isolation of three strains of chikungunya virus. Indian J Med Res. 1964;52:676-83. 
11. Hammon WM, Rudnick A, Sather GE. Viruses associated with epidemic hemorrhagic fevers of the Philippines and Thailand. Science. 1960;131:1102-3.

12. Abdoon AMMO, Alshahrani AM. Prevalence and distribution of anopheline mosquitoes in malaria endemic areas of Asir region, Saudi Arabia. East Mediterr Health J. 2003;9:240-7.

13. Khater El, Sowilem MM, Sallam MF, Alahmed AM. Ecology and habitat characterization of mosquitoes in Saudi Arabia. Trop Biomed. 2013:30:409-27.

14. Al-Azraqi TA, El Mekki AA, Mahfouz AA. Seroprevalence of dengue virus infection in Aseer and Jizan regions, Southwestern Saudi Arabia. Trans R Soc Trop Med Hyg. 2013;107:368-71.

15. Zakham F, Al-habal M, Taher R, Alaoui A, El Mzibri M. Viral hemorrhagic fevers in the Tihamah region of the western Arabian Peninsula. PLoS Negl Trop Dis. 2017 [cited 2021 Jan 24];11. Available from: https://www.ncbi. nlm.nih.gov/pmc/articles/PMC5383019/

16. Leta S, Beyene TJ, De Clercq EM, Amenu K, Kraemer MUG, Revie CW. Global risk mapping for major diseases transmitted by Aedes aegypti and Aedes albopictus. Int J Infect Dis. 2018;67:25-35.

17. Marcombe S, Darriet F, Tolosa M, Agnew P, Duchon S, Etienne M, et al. Pyrethroid Resistance Reduces the Efficacy of Space Sprays for Dengue Control on the Island of Martinique (Caribbean). PLoS Negl Trop Dis [Internet]. 2011 [cited 2021 Jan 24];5. Available from: https://www.ncbi. nlm.nih.gov/pmc/articles/PMC3119637/

18. Thirion L, Pezzi L, Corcostegui I, Dubot-Pérès A, Falchi A, de Lamballerie $\mathrm{X}$, et al. Development and evaluation of a Duo Chikungunya virus real-time RT-PCR assay targeting two regions within the genome. Viruses. 2019;11:755.

19. Verheul MK, Böhringer S, van Delft MAM, Jones JD, Rigby WFC, Gan RW, et al. Triple positivity for anti-citrullinated protein autoantibodies, rheumatoid factor, and anti-carbamylated protein antibodies conferring high specificity for rheumatoid arthritis: implications for very early identification of at-risk individuals. Arthritis Rheumatol. 2018;70:1721-31.

20. Furuya-Kanamori L, Liang S, Milinovich G, Soares Magalhaes RJ, Clements ACA, Hu W, et al. Co-distribution and co-infection of chikungunya and dengue viruses. BMC Infect Dis. 2016;16:84.

21. Fahmy NT, Klena JD, Mohamed AS, Zayed A, Villinski JT. Complete genome sequence of chikungunya virus isolated from an Aedes aegypti mosquito during an Outbreak in Yemen, 2011. Genome Announc. 2015;3:e00789.

22. Malik MR, Mnzava A, Mohareb E, Zayed A, Al Kohlani A, Thabet AAK, et al. Chikungunya outbreak in Al-Hudaydah, Yemen, 2011: epidemiological characterization and key lessons learned for early detection and control. J Epidemiol Glob Health. 2014;4:203-11.

23. Rezza G, El-Sawaf G, Faggioni G, Vescio F, Al Ameri R, De Santis R, et al. Co-circulation of dengue and chikungunya viruses, Al Hudaydah, Yemen, 2012. Emerg Infect Dis. 2014;20:1351-4.

24. Madani TA, Abuelzein E-TME, Al-Bar HMS, Azhar El, Kao M, Alshoeb HO, et al. Outbreak of viral hemorrhagic fever caused by dengue virus type 3 in Al-Mukalla, Yemen. BMC Infect Dis. 2013;13:136.

25. Schwartz O, Albert ML. Biology and pathogenesis of chikungunya virus. Nat Rev Microbiol. 2010;8:491-500.

\section{Publisher's Note}

Springer Nature remains neutral with regard to jurisdictional claims in published maps and institutional affiliations.
Ready to submit your research? Choose BMC and benefit from:

- fast, convenient online submission

- thorough peer review by experienced researchers in your field

- rapid publication on acceptance

- support for research data, including large and complex data types

- gold Open Access which fosters wider collaboration and increased citations

- maximum visibility for your research: over 100M website views per year

At BMC, research is always in progress.

Learn more biomedcentral.com/submissions 